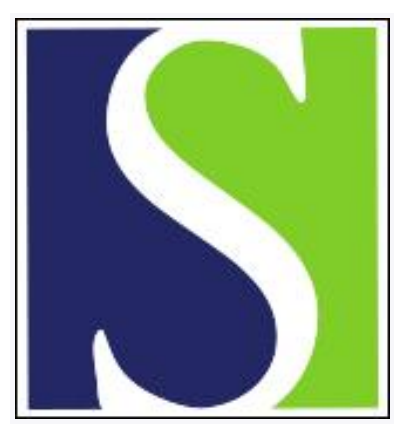

Scand J Work Environ Health 1986;12(1):70-74

https://doi.org/10.5271/sjweh.2172

Issue date: Feb 1986

Biological monitoring of styrene metabolites in blood.

by Lof A, Lundgren E, Nydahl EM, Nordqvist MB

This article in PubMed: www.ncbi.nlm.nih.gov/pubmed/3961444

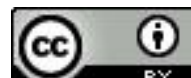




\title{
Biological monitoring of styrene metabolites in blood
}

\author{
by Agneta Löf, MSc, Ebba Lundgren, Eva-Marie Nydahl, Marianne Byfält Nordqvist PhD'
}

LÖF A, LUNDGREN E, NYDAHL E-M, BYFÄLT NORDQVIST M. Biological monitoring of styrene
metabolites in blood. Scand $J$ Work Environ Health (1986) 70-74. Ten men occupationally exposed to
styrene in two glass-fiber reinforced plastics factories were studied during three consecutive workdays.
The mean external exposure level was $99 \mathrm{mg} / \mathrm{m}^{3}$. The total pulmonary uptake of styrene was estimated
from measurements of the styrene concentration in inspired air, the pulmonary ventilation, and the relative
uptake. A gas chromatographic method based on electron capture detection was used to quantify styrene
glycol, as well as styrene-7,8-oxide, in blood. The concentration of styrene glycol appeared to be linearly
related to the preceding uptake of styrene. When the uptake during $5 \mathrm{~h}$ immediately before the blood
sampling was considered, the correlation coefficient $(\mathrm{r})$ obtained the value of 0.90 . The concentration
of styrene-7,8-oxide was at the detection limit of $0.02 \mu$ mol/lin most samples. A weaker correlation between
the concentration of styrene in blood and the uptake during the hour immediately preceding the blood
sampling was obtained $(\mathrm{r}=0.71)$.

Key terms: electron capture detector, field study, gas chromatography, styrene glycol, styrene-7,8-oxide.

Unsaturated polyester resins are commonly used in the manufacturing of glass-fiber reinforced plastics. These resins contain about $40 \%$ styrene as a reactive diluent. Lamination by hand is a common work practice. During this procedure the evaporation of styrene is considerable, and as much as $10 \%$ of the styrene can evaporate into the workroom air. During the lamination process styrene can also be converted to styrene7,8 -oxide in the presence of organic peroxides and air $(10,18)$.

The major metabolic pathway for styrene is the formation of styrene-7,8-oxide (phenyloxirane) by the microsomal cytochrome P-450 system. Styrene-7,8oxide is hydrated to styrene glycol (1-phenyl-1,2ethanediol) by epoxide hydratase. Styrene glycol can either be conjugated with $\beta$-glucuronic acid or oxidized to mandelic acid and phenylglyoxylic acid, which are the two main urinary metabolites of styrene in man (20).

The biological monitoring of workers exposed to organic solvents has gained increasing attention, as air samples do not account for individual variation in work load or physiological factors of importance to the internal exposure. Assessments of occupational exposure to styrene have dealt with the measurement of unaltered styrene in blood, in subcutaneous fat, and in expired air $(1,5,6,8,19,22)$ or the excretion of metabolites in urine (20). The measurement of styrene in blood or expiratory air is of small practical importance, as most of the styrene in the body is elimi-

\footnotetext{
1 Research Department, National Board of Occupational Safety and Health, S-171 84 Solna, Sweden.
}

Reprint requests to: Ms A Löf, Research Department, National Board of Occupational Safety and Health, S-171 84 Solna, Sweden. nated very rapidly. Consequently the concentration of styrene depends to a great extent on the conditions of exposure immediately preceding the collection of specimens. Due to the efficient metabolism of styrene to mandelic and phenylglyoxylic acid and the rapid excretion thereof, the concentration of these acids in the urine immediately after the workshift or in the morning after the exposure are usually used to estimate the average internal exposure. The minor metabolite, 4-vinylphenol, can also be used for biological monitoring, and this metabolite may be of particular toxicologic importance (17).

The present study was carried out to analyze the mutagenic and carcinogenic metabolite styrene-7,8-oxide and its hydrated product styrene glycol in blood after occupational exposure to styrene. An attempt to correlate the concentration of styrene glycol to the uptake of styrene was also undertaken.

\section{Subjects and methods}

\section{Characteristics of the subjects}

Ten healthy men occupationally exposed for 1 to 29 years were studied (table 1). They worked at two factories manufacturing glass-fiber reinforced plastics. Five of the workers were smokers, and the daily average consumption of ethanol was less than $50 \mathrm{~g}$. None of the subjects was on medication.

\section{Styrene concentration in inspired air}

Plant 1 (Sweden). Air from the breathing zone of workers in plant 1 was sampled with a passive dosimeter (3M Brand organic vapor monitor 3500 ). The adsorbed styrene was eluted with carbon disulfide and 
analyzed by gas chromatography (10\% carbowax 400 on chromosorb $\mathrm{W}, 2.0 \mathrm{~m}, 90^{\circ} \mathrm{C}$, nitrogen flow 30 $\mathrm{ml} / \mathrm{min}$, flame ionization detector, Varian 3700 ). The error of the gas chromatographic method was $\pm 3 \%$.

Plant 2 (Switzerland). Air samples were collected in charcoal tubes. Styrene was desorbed from the charcoal with carbon disulfide containing toluene as the internal standard and analyzed by gas chromatography (Apiezon, $2.8 \mathrm{~m}, 2 \mathrm{~min}$ at $70^{\circ} \mathrm{C}$, to $110^{\circ} \mathrm{C}$ at $10^{\circ} \mathrm{C} / \mathrm{min}$, $3 \mathrm{~min}$ at $110^{\circ}$, nitrogen flow $30 \mathrm{ml} / \mathrm{min}$, Perkin Elmer model 3). The error of the gas chromatographic method was $\pm 5 \%$.

\section{Styrene uptake}

Pulmonary ventilation was measured with a Wright respirometer (Medishield Harlow, Essex CM $195 \mathrm{AB}$, England). Measurements were performed during the various phases of work and during the breaks. The duration of the different periods was measured. For the different subjects and the separate workdays the uptake was calculated as the product of styrene concentration in inspired air, pulmonary ventilation, and relative uptake. ${ }^{2}$ From experimental exposure of preexposed volunteers the relative uptake was assumed to be $63 \%$ (A Löf et al, to be published). In plant 1 the uptake measurements were restricted to periods of 1,2 , and $5 \mathrm{~h}$ prior to the times of blood sampling, while in plant 2 the uptake of styrene was measured during the whole workday.

\section{Styrene concentration in blood}

Blood from a brachial vein was sampled in a room separate from the work area to avoid contamination. At plant 1 samples were taken before work at 0700 and immediately after exposure at 0900 and at 1200 . At plant 2 the blood samples were taken at the end of the workday between 1700 and 1800 .

For the analysis of styrene in blood (plant 1), samples of $1 \mathrm{ml}$ were equilibrated with air at $37^{\circ} \mathrm{C}$ for 20 min in citrate-treated headspace bottles. Headspace air was analyzed for styrene by gas chromatography ( $3 \%$ SE-30 on chromosorb GAW, $2.0 \mathrm{~m}, 130^{\circ} \mathrm{C}$, nitrogen flow $20 \mathrm{ml} / \mathrm{min}$, flame ionization detector, Perkin Elmer F 33). The error of the headspace method was estimated to be $\pm 7 \%$. For further details see the report of Wigaeus et al (21).

\section{Styrene 7,8-oxide and styrene glycol concentration in blood}

Styrene-7,8-oxide and styrene glycol in blood were analyzed after an extraction procedure. Styrene-7,8oxide was extracted with hexane (Merck, analytical

\footnotetext{
2 Relative uptake $(\%)=100 \times\left(C_{i n}-C_{e x}\right) / C_{i n}$, with $C_{i n}=$ the solvent concentration in inspired air and $\mathrm{C}_{\mathrm{ex}}=$ the solvent concentraton in expired air.
}

Table 1. Characteristics of the subjects.

\begin{tabular}{|c|c|c|c|c|}
\hline & \multicolumn{2}{|c|}{$\begin{array}{l}\text { Plant } 1 \\
(\mathrm{~N}=6)\end{array}$} & \multicolumn{2}{|c|}{$\begin{array}{l}\text { Plant } 2 \\
(N=4)\end{array}$} \\
\hline & Mean & Range & Mean & Range \\
\hline $\begin{array}{l}\text { Age (years) } \\
\text { Weight }(\mathrm{kg}) \\
\text { Height }(\mathrm{cm}) \\
\text { Exposure time (years) } \\
\text { Smokers }(\mathrm{N})\end{array}$ & $\begin{array}{r}35 \\
77 \\
177 \\
10 \\
3\end{array}$ & $\begin{array}{c}25-42 \\
69-105 \\
170-180 \\
7-12 \\
.\end{array}$ & $\begin{array}{r}38 \\
84 \\
176 \\
15 \\
2\end{array}$ & $\begin{array}{c}25-51 \\
64-114 \\
167-181 \\
1-29 \\
.\end{array}$ \\
\hline
\end{tabular}

grade) and then styrene glycol with ethyl acetate (Merck, analytical grade). Conjugated styrene glycol was hydrolyzed by $\beta$-glucuronidase type H-1 (Sigma) in $0.07 \mathrm{M}$ acetate buffer $\mathrm{pH} 5.0$ at $37^{\circ} \mathrm{C}$ overnight. Acidification with sulfuric acid $(0.5 \mathrm{M})$ converted styrene-7,8-oxide to styrene glycol, which was derivatized with pentafluorobenzoyl chloride (Aldrich $98 \%$ ) and analyzed by a gas chromatographic technique based on electron capture detection (3). Allylbenzene glycol was used as an internal standard.

In the determination of styrene-7,8-oxide and nonconjugated styrene glycol the gas chromatographic conditions were as follows: $3 \%$ SE-30 on chromosorb GAW-DMCS, $2.0 \mathrm{~m}, 220^{\circ} \mathrm{C}$, nitrogen flow $50 \mathrm{ml} / \mathrm{min}$, Carlo Erba FTV 2350. Styrene-7,8-oxide was also analyzed on a capillary column, as was conjugated styrene glycol after hydrolysis (BP-1-0.25, $0.2 \mathrm{~mm} \times 12$ $\mathrm{m}, 230^{\circ} \mathrm{C}$, helium flow $1.5 \mathrm{ml} / \mathrm{min}$, Carlo Erba FTV 2350). The detection limit was $0.02 \mu \mathrm{mol} / \mathrm{l}$ for styrene-7,8-oxide and conjugated styrene glycol and $0.08 \mu \mathrm{mol} / \mathrm{l}$ for free styrene glycol. The error of the method was $\pm 15 \%$ for styrene glycol at concentrations below $1 \mu \mathrm{mol} / 1$.

\section{Statistical treatment}

The calculation of the error of the method was based on the differences between double determinations and expressed as the percentage of the mean value. Linear regression lines were calculated with the method of the least square fitting.

\section{Results and discussion}

During the $3 \mathrm{~d}$ of study the styrene concentration in the breathing zone of the 10 subjects varied between 5 and $371 \mathrm{mg} / \mathrm{m}^{3}$ with an average level of $99 \mathrm{mg} / \mathrm{m}^{3}$ [plant 1: 44 (SD 21) $\mathrm{mg} / \mathrm{m}^{3}$; plant 2: 182 (SD 86) $\left.\mathrm{mg} / \mathrm{m}^{3}\right]$. The internal exposure to styrene took place mainly in the morning.

The styrene concentration in venous blood was only measured in subjects working at plant 1 and was 0.5 (SD 0.1$) \mu \mathrm{mol} / \mathrm{l}$ at the start of the workdays. The best correlation $(r=0.71)$ between the styrene concentration in blood and the uptake of styrene was, as expected, seen when the uptake measurement was con- 


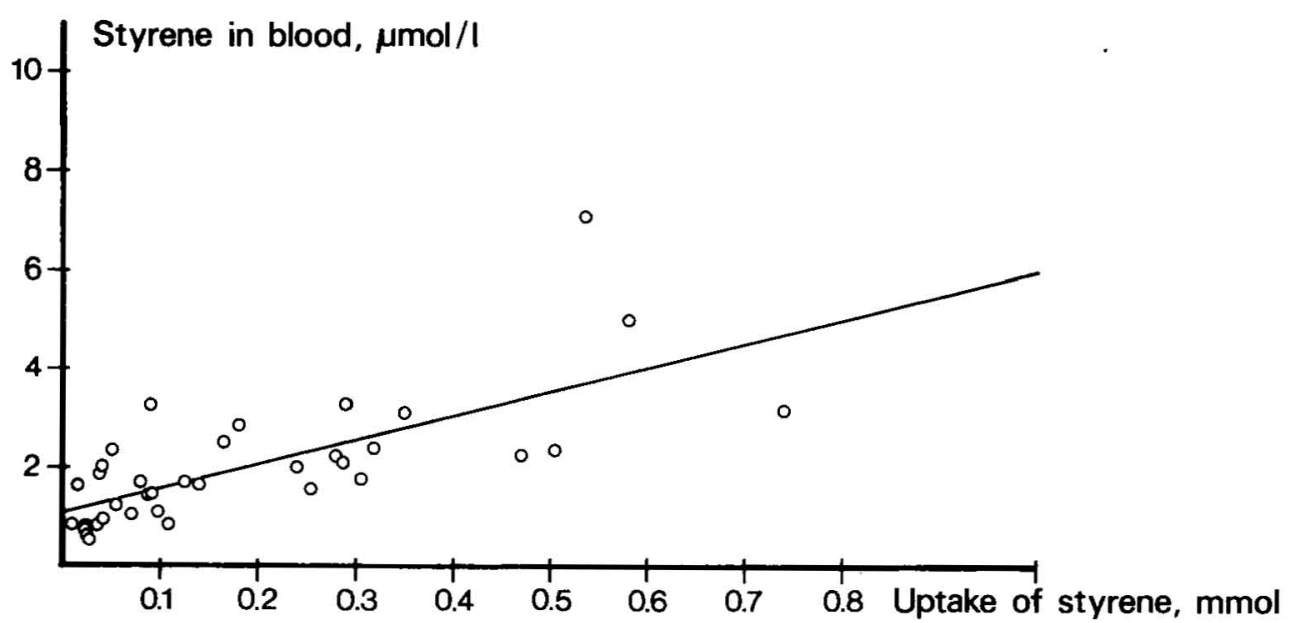

Figure 1. Concentration of styrene in the venous blood of six subjects (plant 1 ) in relation to the uptake of styrene measured during $1 \mathrm{~h}$ immediately before the blood sampling $(r=0.71)$.

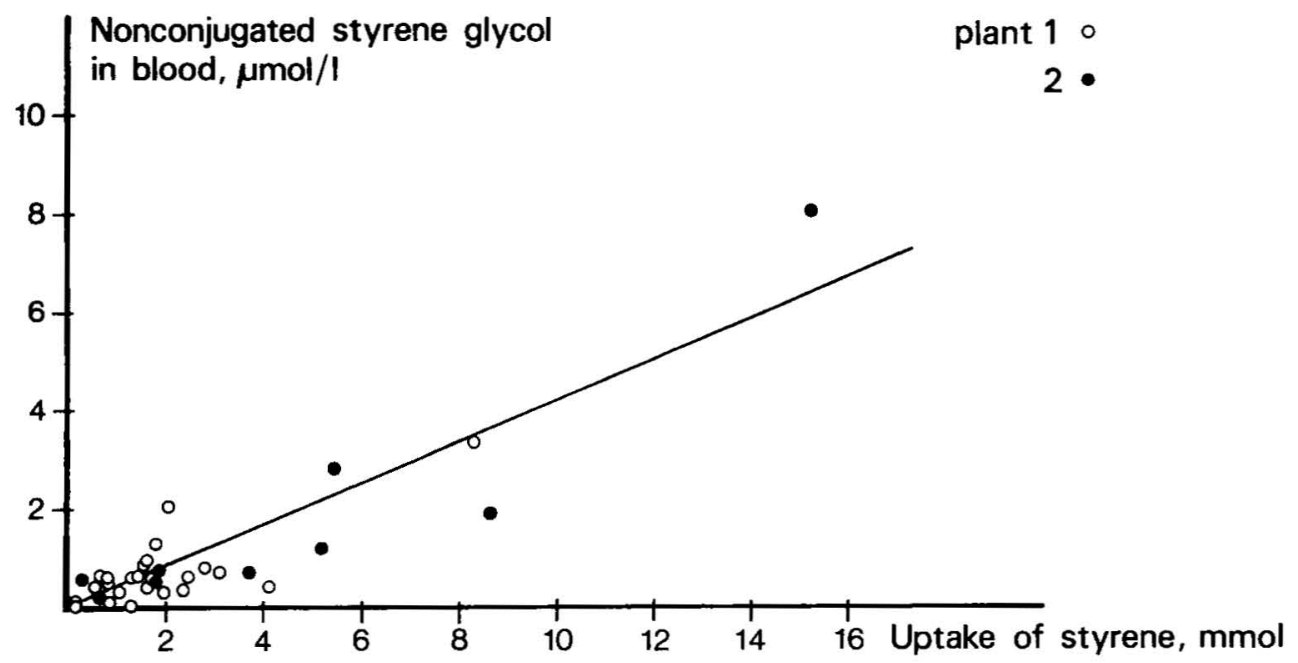

Figure 2. Concentration of nonconjugated styrene glycol in the venous blood of 10 subjects (plant 1 and 2 ) in relation to the uptake of styrene measured during $5 \mathrm{~h}$ immediately before the blood sampling $(r=0.90)$.

fined to $1 \mathrm{~h}$ immediately preceding the blood sampling (figure 1). Due to the rapid metabolism of styrene and its distribution to adipose tissue (21) the concentration of styrene in blood mainly reflects the exposure immediately preceding the sampling of the blood specimen.

The concentration of nonconjugated styrene glycol in blood increased with the preceding uptake of styrene (figure 2). We have earlier shown a linear increase in the concentration of nonconjugated styrene glycol throughout an experimental exposure to styrene for $2 \mathrm{~h}$ at $300 \mathrm{mg} / \mathrm{m}^{3}(21)$. In that study we also found a high interindividual variation in the blood concentration of nonconjugated styrene glycol, as well as styrene, after similar uptake, which was attributed to differences in metabolic clearance. In spite of this oc- currence the obtained correlation coefficient between nonconjugated styrene glycol and styrene uptake during the preceding $5 \mathrm{~h}(\mathrm{r}=0.90)$ was acceptable. It was comparable to that reported for the correlation between mandelic acid and phenylglyoxylic acid excreted in the urine and the uptake or air concentration of styrene $(2,4,7,9,11,12,13,14)$. An equivalent correlation $(r=0.91)$ was seen between the total amount of styrene glycol and the preceding uptake. The amount of styrene glycol conjugated with $\beta$-glucuronic acid was 51 (SD 24) \%. At plant 2 a good correlation was also obtained when the uptake was measured for $4,6,7$, and $8 \mathrm{~h}$, respectively, immediately before the blood sampling.

Changes in the level of the physical activity of the workers, as well as large fluctuations of the styrene 
concentration in the air, may introduce errors in the uptake estimates of styrene. As a consequence the correlation between styrene glycol and the real uptake may be higher than what was obtained in the present investigation. One drawback to the use of styrene glycol in blood as a monitor of styrene exposure is the elimination half-time of nonconjugated styrene glycol of approximately $50 \mathrm{~min}$ (A Löf et al, to be published). Therefore the measured blood concentration of styrene glycol will be lower than expected from the uptake if the exposure mostly occurs in the beginning of the uptake monitoring.

In biological monitoring the relatively short halftime of styrene glycol could lead to an underestimation of the previous exposure to styrene. The reverse could happen if the exposure mainly occurs immediately before the blood sampling. Urinary metabolites are often used to demonstrate earlier exposure to styrene. However, these methods generally do not give any indication of the health hazards involved. The analysis of styrene glycol in blood may be of particular toxicologic importance, as glycol itself has been pointed out to be a central nervous system depressant (16), and it can also be assumed to reflect the levels of its carcinogenic precursor styrene-7,8-oxide.

The concentration of styrene-7,8-oxide was at the detection limit of $0.02 \mu \mathrm{mol} / 1$ in most samples. Only in one blood sample a somewhat higher concentration $(0.04 \mu \mathrm{mol} / 1)$ was found. That observation was made in a sample from the worker with the highest uptake of styrene during the last $5 \mathrm{~h}$ of exposure and the highest blood concentration of nonconjugated styrene glycol, which indicates a possibility to analyze styrene7,8-oxide in blood from workers exposed to high concentrations of styrene. (See references 15 and 21.)

In conclusion, it appears that the analysis of styrene glycol in blood sampled at the end of the workday or earlier during the day may be one way to estimate the internal exposure to styrene earlier during the same day. Either the free styrene glycol or the sum of free and conjugated styrene glycol can be correlated to the uptake. The method for the former has the advantage of being analytically simpler as it is not necessary to cleave the conjugated styrene glycol. The advantage of the latter is an increased sensitivity. The influence of varying exposure on the blood level of styrene glycol with time needs to be investigated further.

\section{Acknowledgments}

The authors are very grateful to Ms E Gullstrand for her technical assistance and to Ms M-B Cedervall for preparing the manuscript. We also express 'our gratitude to Dr PO Droz and Dr J Sollenberg for the valuable blood samples.

\section{References}

1. Åstrand I, Kilbom Å, Övrum P, Wahlberg I, Vesterberg $\mathrm{O}$. Exposure to styrene: I Concentration in alveolar air and blood at rest and during exercise and metabolism. Work Environ Health 11 (1974) 69-85.

2. Apostoli P, Brugnone F, Perbellini L, Cocheo V, Bellomo ML, Silvestri R. Occupational styrene exposure: Environmental and biological monitoring. Am $\mathbf{J}$ Ind Med 4 (1983) 741-754.

3. Duverger-van Bogaert M, Noël G, Rollman B, Cumps J, Roberfroid M, Mercier M. Determination of oxide synthetase and hydratase activities by a new highly sensitive gas chromatographic method using styrene and styrene oxide as substrates. Biochim Biophys Acta 526 (1978) $77-84$.

4. Elia VJ, Anderson LA, MacDonald TJ, Carson A, Buncher CR, Brooks SM. Determination of urinary mandelic and phenylglyoxylic acids in styrene exposed workers and a control population. Am Ind Hyg Assoc J 41 (1980) 922-926.

5. Engström J, Ástrand I, Wigaeus E. Exposure to styrene in a polymerization plant: Uptake in the organism and concentration in subcutaneous adipose tissue. Scand J Work Environ Health 4 (1978) 324-329.

6. Engström J, Bjurström R, Astrand I, Övrum P. Uptake, distribution and elimination of styrene in man: Concentration in subcutaneous adipose tissue. Scand J Work Environ Health 4 (1978) 315-323.

7. Engström K, Härkönen H, Kalliokoski P, Rantanen J. Urinary mandelic acid concentration after occupational exposure to styrene and its use as a biological exposure test. Scand J Work Environ Health 2 (1976) 21-26.

8. Fernandez JG, Caperos JR. Styrene exposure: An experimental study of pulmonary absorption and excretion. Int Arch Occup Environ Health 40 (1977) 1-12.

9. Fields RL, Horstman SW. Biomonitoring of industrial styrene exposure. Am Ind Hyg Assoc J 40 (1979) 451459.

10. Fjeldstad PE, Thorud S, Wannag A. Styrene oxide in the manufacture of reinforced polyester plastics. Scand J Work Environ Health 5 (1979) 162-163.

11. Götell P, Axelson O. Lindelöf B. Field studies on human styrene exposure. Work Environ Health 9 (1972) 76-83.

12. Guillemin MP, Bauer D, Martin B, Marazzi A. Human exposure to styrene: IV Industrial hygiene investigations and biological monitoring in the polyester industry. Int Arch Occup Environ Health 51 (1982) 139-150.

13. Härkönen $H$, Kalliokoski P, Hietala $S$, Hernberg S. Concentrations of mandelic and phenylglyoxylic acid in urine as indicators of styrene exposure. Work Environ Health 11 (1974) 162-169.

14. Ikeda M, Koizumi A, Miyasaka M, Watanabe T. Styrene exposure and biologic monitoring in FRP boat production plants. Int Arch Occup Environ Health 49 (1982) $325-339$.

15. Löf A, Gullstrand E, Lundgren E, Byfält Nordqvist $M$ Occurrence of styrene-7,8-oxide and styrene glycol in mouse after the administration of styrene. Scand J Work Environ Health 10 (1984) 179-187.

16. Parkki MG, Marniemi J, Vainio H. Action of styrene and its metabolites styrene oxide and styrene glycol on activities of xenobiotic biotransformation enzymes in rat liver in vivo. Toxicol Appl Pharmacol 38 (1976) 59-70.

17. Pfäffli P, Hesso A, Vainio H, Hyvönen M. 4-Vinylphenol excretion suggestive of arene oxide formation in workers occupationally exposed to styrene. Toxicol Appl Pharmacol 60 (1981) 85-90.

18. Pfäffli P, Vainio H, Hesso A. Styrene and styrene oxide concentrations in the air during the lamination process in the reinforced plastics industry. Scand $\mathrm{J}$ Work Environ Health 5 (1979) 158-161. 
19. Steward RD, Dodd HC, Baretta ED, Schaffer AW, Human exposure to styrene vapor. Arch Environ Health $16(1968) 656-662$.

20. Vainio H, Hietanen E, Belvedere G. Pharmacokinetics and metabolism of styrene. In: Bridges JW, Chasseaud LF, ed. Progress in drug metabolism. Volume 8. Taylor \& Francis Ltd, London 1984, pp 203-239.

21. Wigaeus E, Löf A, Bjurström R, Byfält Nordqvist $M$. Exposure to styrene: Uptake, distribution, metabolism and elimination in man. Scand J Work Environ Health 9 (1983) 479-488.

22. Wolff MS, Daum SM, Lorimer WV, Selikoff IJ, Aubrey BB. Styrene and related hydrocarbons in subcutaneous fat from polymerization workers. J Toxicol Environ Health 2 (1977) 997-1005.

Reveived for publication: 28 October 1985 